\title{
SRPSKA I RUMUNSKA DNEVNA ŠTAMPA O PROBLEMU ZLOSTAVLJANJA DECE ${ }^{1}$
}

Cilj ovog rada je da se istraži na koji način srpska i rumunska dnevna štampa izveštavaju o problemu zlostavljanja dece. Namera autorke je da uradi analizu tekstova na ovu temu objavljenih u rumunskom dnevnom listu Adevărul odnosno srpskom dnevnom listu Blic, u periodu 1. januar 2011 - 31. januar 2012. godina, prema unapred utvrđenom kodeksu. Imajući u vidu gore navedeno, analiziraće se veličina teksta, žanr, autorstvo, povod, vizuelna prezentacija, lokacija, tema, subjekat, objekat, vrednosni kontekst i tip naslova, sa namerom da se utvrde sličnosti i razlike u bavljenju dvaju lista ovom temom.

Ključne reči: dnevna štampa, deca, zlostavljanje, Adevărul, Blic

\section{UVODNE NAPOMENE}

Nasilje nad decom predstavlja pojavu koja je stara koliko i čovečanstvo (Mihić 2002: 51). O tome svedoče brojni dokazi iz bliže i dalje istorije, pa je tako zabeleženo surovo kažnjavanje i ubijanje dece još kod antičkih naroda - Sumera, Grka i Rimljana, kada se ovakvo ponašanje smatralo roditeljskim pravom (Mihić 2002: 51). Razni oblici primene nasilja u procesu vaspitavanja zabeleženi su i u srednjem veku, ali ni građansko društvo nije mnogo odmaklo od ovako surovog postupanja prema deci u porodici, pa su osim različitih oblika fizičkog nasilja nad decom, zabeleženi i slučajevi surovog ubijanja sopstvene dece u radničkim porodicama (Mihić 2002: 51).

Danas nasilje nad decom podrazumeva kontinuum nehumanih odnosa, koja se kreću od zapostavljanja - nedovoljna briga za ravojne potrebe i ličnost deteta, preko zanemarivanja - odsustvo ili skučene mogućnosti zadovoljavanja razvojnih

1 Rad je realizovan u okviru projekta br. III47020 Digitalne medijske tehnologije i društvenoobrazovne promene. 
i osnovnih potreba i socijalne sigurnosti deteta, do zlostavljanja - ugrožavanje psihičkog i fizičkog integriteta ličnosti deteta i napad na njegovu samosvojnost i posebnost (Milosavljević 1998: 21).

Prema podacima Međunarodne unije za zaštitu detinjstva u visokorazvijenim zemljama roditelji su odgovorni za smrt svoje dece više od bolesti poput tuberkuloze, dečje paralize, boginja ili dijabetesa zajedno (Banjanin-Đuričić 1998). Takođe, National Assault Prevention Center u Nju Džerziju je sprovelo istraživanje koje je dovelo de sledećih otkrića:

- na svakih 47 sekundi jedno dete je napadnuto ili zanemareno;

- svaka dva i po sata jedno dete je ubijeno (većina ih je ispod 5 godina starosti, a čak 53\% ispod jedne godine života);

- jedna od 3 devojčice i jedan od 6 dečaka su seksualno napadani bar jednom do 18 godine;

- $\quad$ preko $85 \%$ zlostavljane dece je napadnuto od nekoga koga su poznavali ili u koga su imali poverenja (Lakić 1998: 34).

Razvojne specifičnosti deteta i još uvek nedovoljno razvijeni mehanizmi odbrane, kao i nedostatak neophodne ljubavi i podrške, čini da nasilje kojem je izloženo, pored trauma i fizičkih tragova koje sa sobom nosi, predstavlja i smetnju pravilnom formiranju njegove ličnosti, psihičkom i socijalnom razvoju (Gašić-Marušić 1998: 51).

Posledice zlostavljanja i zanemarivanja u ranom detinjstvu na psihološki razvoj deteta, kao i na kasnije mentalno zdravlje, detaljno su proučavane u poslednjim decenijama. Neke od njih su kašnjenje u kognitivnom razvoju, niži koeficijent inteligencije (Koenen, Moffitt, Caspi, Taylor, Purcell 2003; prema: Samardžić, Nikolić, Grbeša, Simonović, Milenković 2010: 654), neurobiološke abnormalnosti (Glaser 2000; prema: Samardžić et al. 2010: 654), disfunkcionalnost u ponašanju, agresija i zloupotreba psihoaktivnih supstanci (Fergusson, Horwood, Lynskey 1997; Schuck, Widom 2001; prema: Samardžić et al. 2010: 654), kao i povećani rizik od adolescentnih i adultnih psihijatrijskih poremećaja (Schuck, Widom 2001; Brown, Cohen, Johnson, Smailes 1999; Fergusson, Lynskey 1997; Lansford, Dodge, Pettit, Bates, Crozier, Kaplow 2002; Collishaw, Pickles, Messer, Rutter, Shearer, Maughan 
2007; prema: Samardžić et al. 2010: 654).

Pravni sistem ima ključnu ulogu u društvenoj reakciji na zlostavljanje dece u tom smislu što pravo definiše oblike ponašanja koji narušavaju odnos prema detetu oblikovan socio-kulturnim standardima i utvrđuje stepen društvene tolerancije, odnosno kriterijume za intervencije države u procese podizanja i vaspitanja dece (Obretković 1998: 97). Tako su uloge obrazovnih i zdravstvenih ustanova najveće u oblasti primarne prevencije, uloga sistema socijalne zaštite - na planu sekundarne prevencije, dok pravni sistem ima ključnu ulogu u primeni zaštitnih intervencija u konkretnim slučajevima zaštite nad decom (Obretković 1999: 4).

Najpotpuniji pravni izvor u zaštiti dece od nasilja je Konvencija o pravima deteta, koja državama potpisnicama nalaže da se preduzmu sve mere u smislu zaštite deteta od svih oblika fizičkog i psihičkog nasilja, povređivanja i zlostavljanja, zapostavljanja ili nemarnog postupanja, maltretiranja ili eksploatacije, uključujući seksualno zlostavljanje (Mršević, Milivojević, Ćopić 2000: 13).

\section{ANALIZA EMPIRIJSKOG MATERIJALA}

\subsection{Korpus}

Istraživački korpus čine tekstovi o zlostavljanju dece objavljenih u rumunskom dnevnom listu Adevărul, odnosno srpskom dnevnom listu Blic, u periodu 1. januar 2011 - 31. januar 2012. godina². Analizirano je ukupno 65 tekstova, 40 u Adevărul, 25 u Blicu, prema unapred utvrđenom kodeksu koji obuhvata: veličinu teksta, medijski žanr, autorstvo teksta, povod izveštavanja, vizuelnu prezentaciju, lokaciju, temu, subjekat, objekat, vrednosni kontekst u koji je postavljen objekat, tip naslova.

\subsection{Rezultati istraživanja}

\subsubsection{Veličina teksta}

$\mathrm{Na}$ osnovu analize, zaključujemo da u rumunskom dnevnom listu Adevărul od ukupno 40 tekstova, najviše je velikih - 17 (42,5\%), 15 je srednje veličine $(37,5 \%)$, a 8 tekstova spada u red kratkih $(20 \%)^{3}$. Kada je reč o Blicu, od ukupno 25 tekstova, 9 (47\%) spada u red tekstova srednje dužine, 8 tekstova (32\%) spada u red

2 Tekstovi na datu temu preuzeti su iz onlajn arhive dnevnih listova Adevărul i Blic.

3 Kratak tekst - nekoliko rečenica; srednji-do trećine stranice; velik - polovina i više od polovine stranice. 
kratkih, a isti broj tekstova $-8(32 \%)$ spada u red velikih.

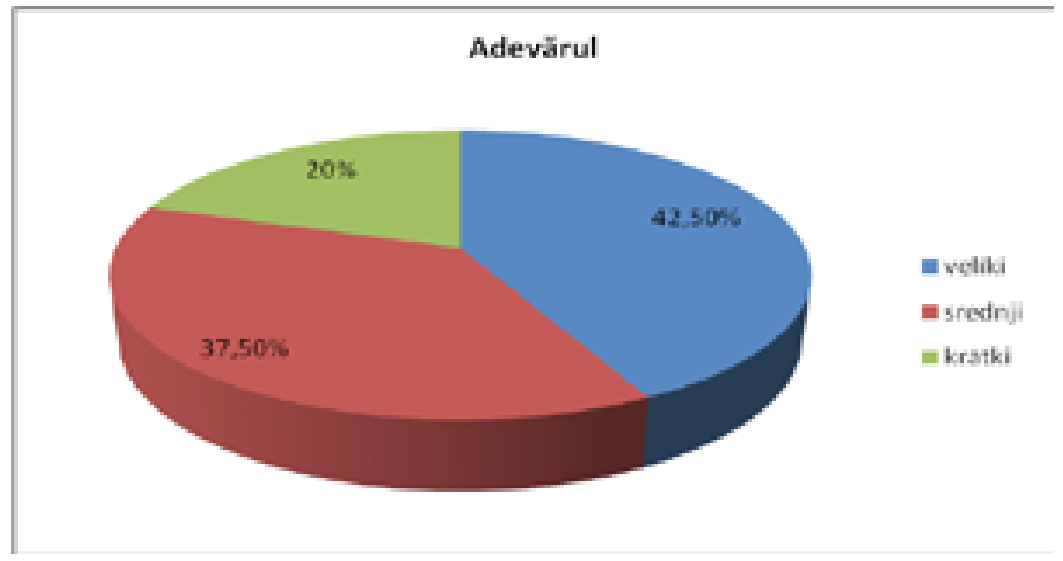

Grafikon 1. Veličina teksta - Adevărul

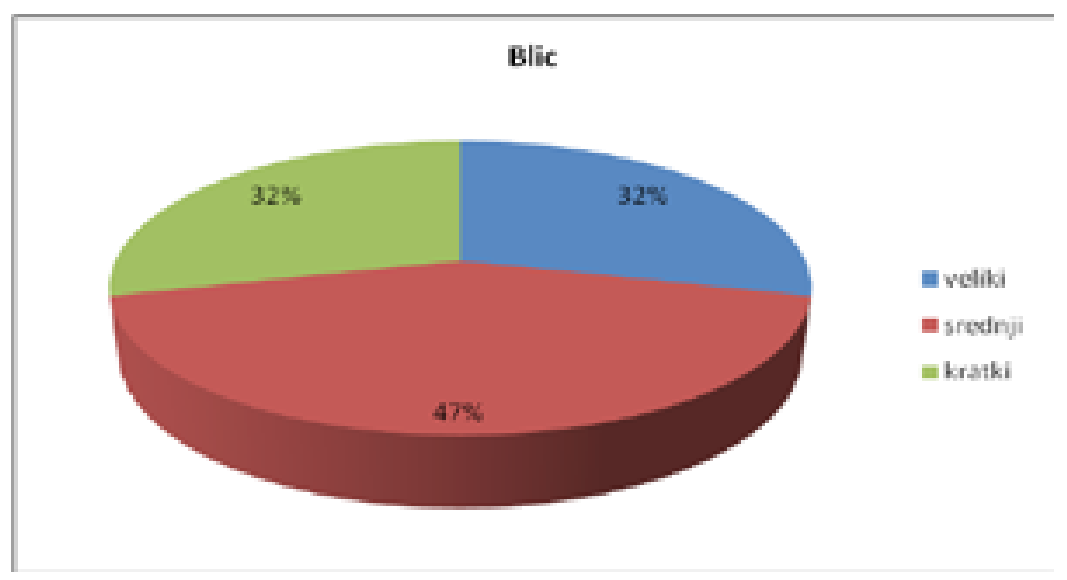

Grafikon 2. Veličina teksta - Blic

\subsubsection{Medijski žanr}

Od novinskih žanrova, o oba lista dominira članak - 36 puta $(90 \%)$ u Adevărul, 21 put (84\%) u Blicu; uz članak kao medijski žanr beležimo i reportažu i vest; reportaža se kao medijski žanr pojavljuje u Adevărul - 4 puta (10\%), dok se vest pojavljuje u Blicu - 4 puta (16\%). 


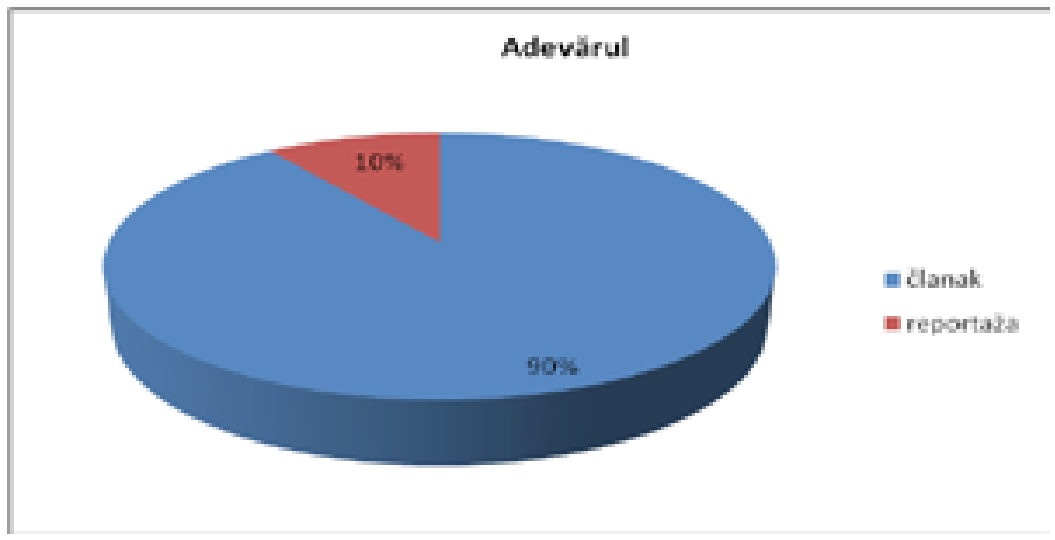

Grafikon 3. Medijski žanr - Adevărul

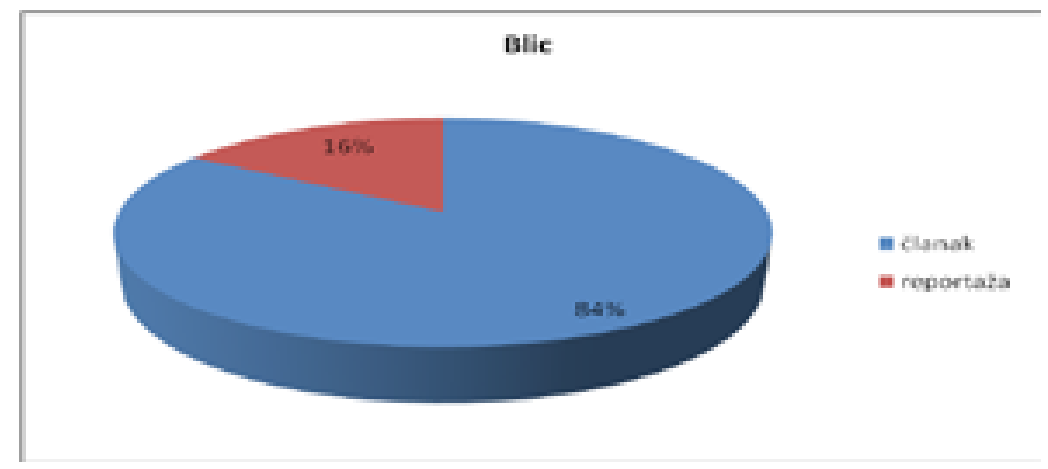

Grafikon 4. Medijski žanr - Blic

\subsubsection{Autorstvo teksta}

$\mathrm{U}$ dnevnom listu Adevărul svi analizirani prilozi su potpisani punim imenom i prezimenom novinara (100\%); u Blicu 7 priloga (28\%) je potpisano punim imenom i prezimenom novinara, 1 prilog (4\%) je potpisan inicijalima novinara, 17 puta (68\%) autorstvo pripada agenciji. 


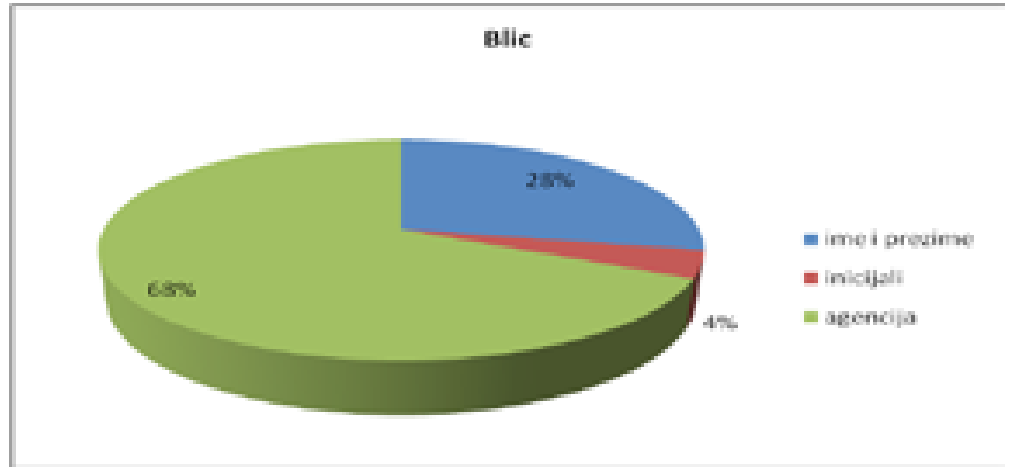

Grafikon 5. Autorstvo teksta - Blic

\subsubsection{Povod izveštavanja}

U vezi sa povodom izveštavanja, zaključujemo da u oba dnevna lista dominira aktuelni događaj, 23 puta (57,5\%) u Adevărul, 21 put (84\%) u Blicu; uz aktuelni događaj beležimo i medijsku inicijativu kao povod izveštavanja, 17 puta $(42,5 \%) \mathrm{u}$ Adevărul, 4 puta (16\%) u Blicu.

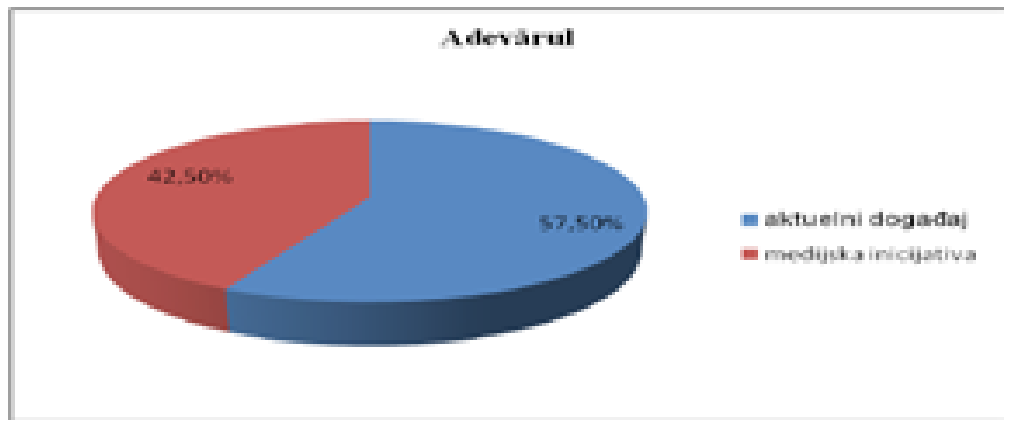

Grafikon 6. Povod izveštavanja - Adevărul 


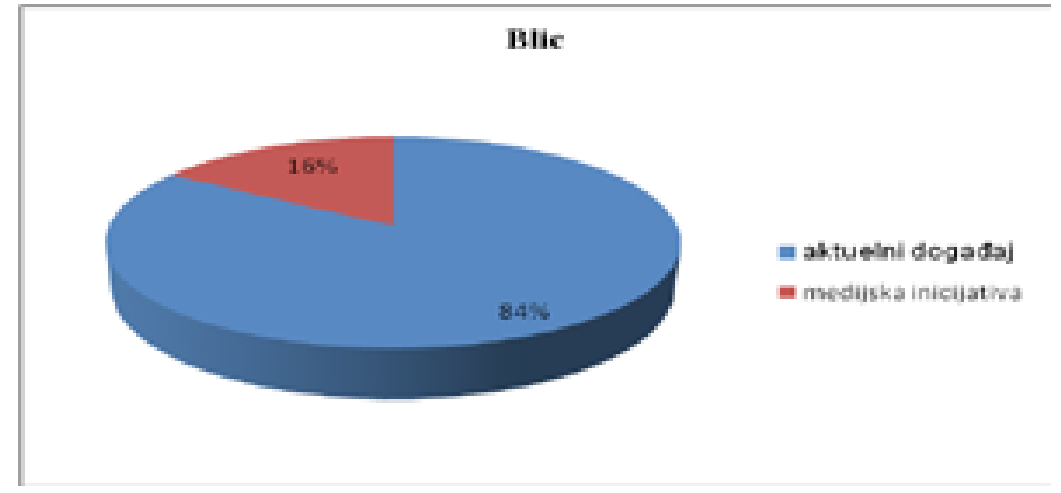

Grafikon 7. Povod izveštavanja - Blic

\subsubsection{Vizuelna prezentacija}

Kada je reč o vizuelnoj prezentaciji, rezultati pokazuju da je u rumunskom dnevnom listu fotografija uvek prisutna uz tekst (100\%); u srpskom dnevnom listu 9 puta (36\%) se pojavljuje samo tekst bez fotografije, 11 puta (44\%) imamo kombinaciju tekst + fotografija, a 5 puta $(20 \%)$ imamo kombinaciju tekst + fotografija + antrfile. Na fotografijama se najčešće nalaze deca.

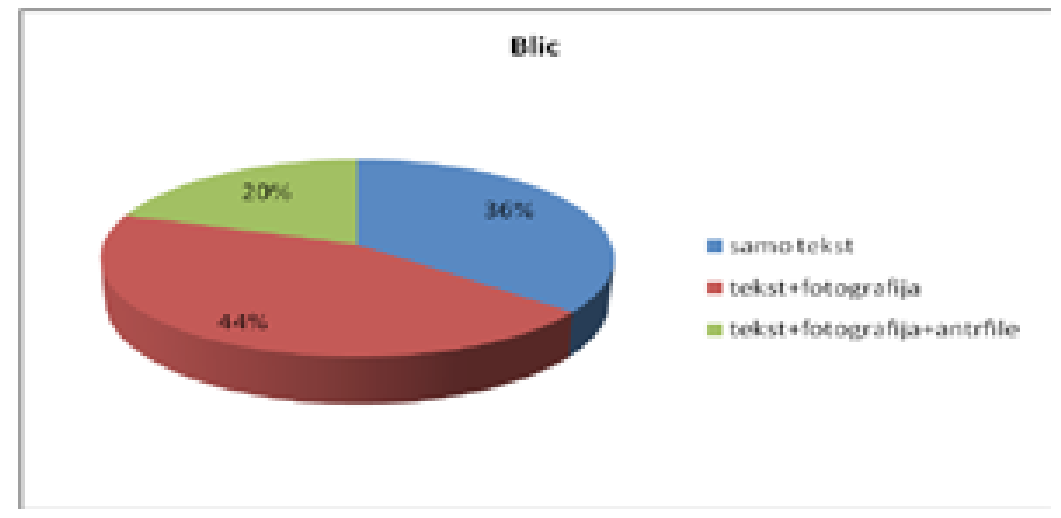

Grafikon 8. Vizuelna prezentacija - Blic

\subsubsection{Lokacija}

U rumunskom dnevnom listu Adevărul najčešće mesto zbivanja događaja je Rumunija - 27 puta (67,5\%), sledi Republika Moldavija - 9 puta (22,5\%), SAD - 2 puta (5\%), Velika Britanija - 1 put (2,5\%), Švajcarska - 1 put (2,5\%). U Blicu na prvom mestu je Srbija - 10 puta (38\%), sledi region: Hrvatska -2 puta (8\%), BiH - 2 
puta (8\%), Makedonija - 1 put (4\%), Kosovo - 1 put (4\%), zatim evropske zemlje: Nemačka - 2 puta (8\%), Italija - 2 puta (8\%), Irska - 1 put (4\%), Holandija - 1 put (4\%), Malta - 1 put (4\%), kao i Kanada - 1 put (4\%) i Brazil - 1 put (4\%); 1 put lokacija nije specifikovana.

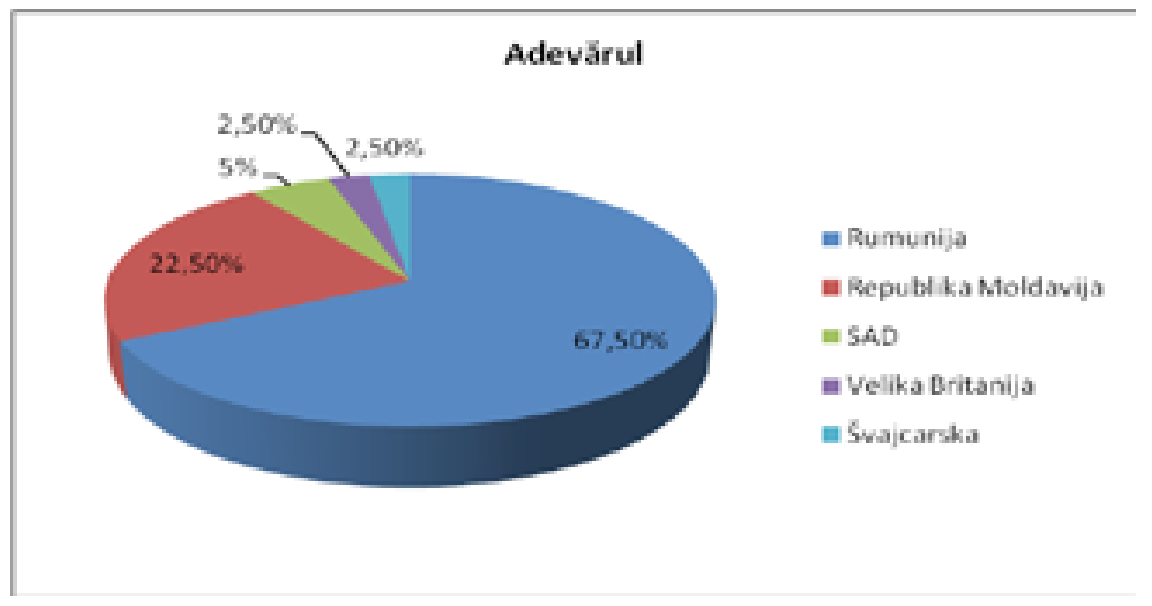

Grafikon 9. Lokacija - Adevărul

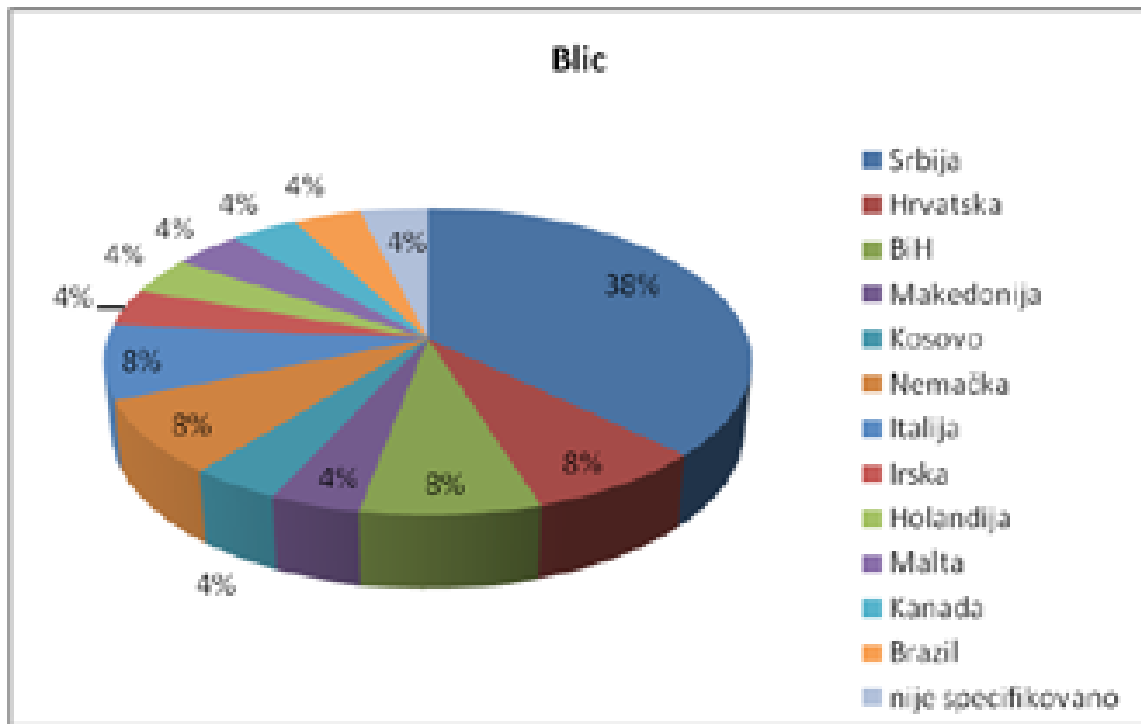

Grafikon 10. Lokacija - Blic 
Govoreći o temi, na osnovu rezultata zaključujemo da je u oba dnevna lista glavna tema nasilje nad decom, sa sledećim potkategorijama:

a) Adevărul:

- $\quad$ porodično nasilje (roditelj počinilac nasilja) - 10 puta (25\%);

- porodično nasilje + seksualno nasilje zajedno tretirano u prilogu (roditelj počinilac nasilja) - 18 puta (45\%);

- $\quad$ seksualno nasilje (roditelj počinilac nasilja) - 2 puta (5\%);

- $\quad$ pedofilija + seks trafiking zajedno tretirano u prilogu -6 puta $(15 \%)$;

- nasilje nad decom vršeno od strane drugih osoba - 2 puta (5\%);

- zlostavljanje dece i potencijalne opasnosti onlajn komunikacije - 1 put $(2,5 \%)$;

- zlostavljanje dece i posledice seksualnog nasilja - 1 put (2,5\%).

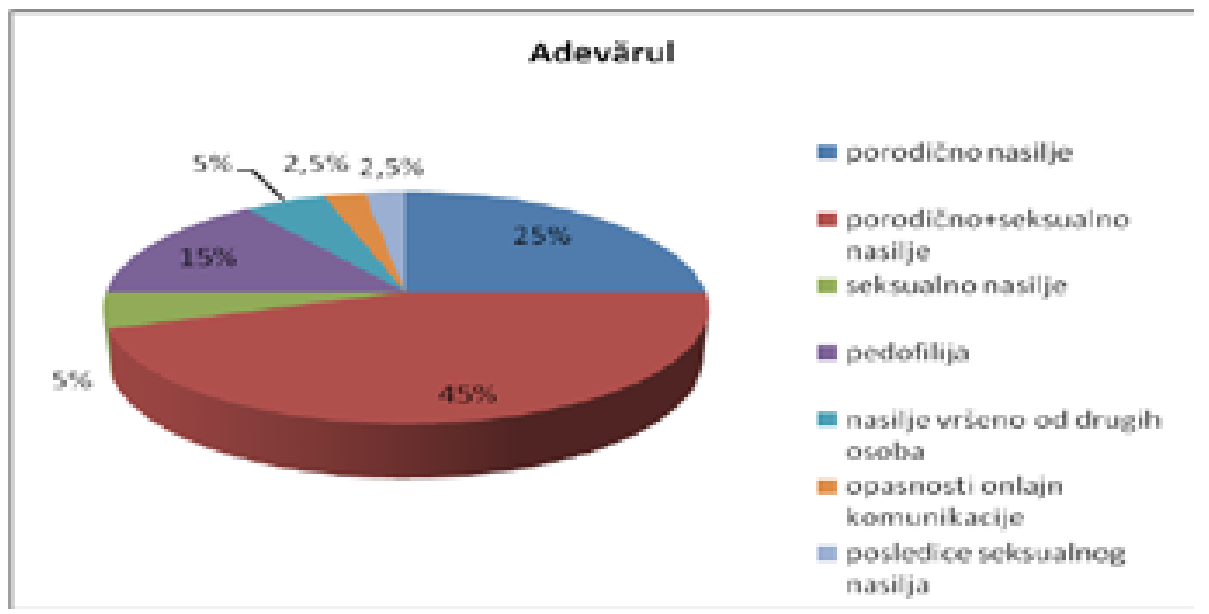

Grafikon 11. Teme izveštavanja - Adevărul

b) Blic:

- $\quad$ porodično nasilje (roditelj počinilac nasilja) - 3 puta (12\%);

- porodično nasilje + seksualno nasilje zajedno tretirano u prilogu (roditelj počinilac nasilja) - 4 puta $(16 \%)$;

- $\quad$ seksualno nasilje (roditelj počinilac nasilja) - 3 puta (12\%),

- $\quad$ pedofilija - 14 puta (56\%);

- $\quad$ seks trafiking - 1 put (4\%). 


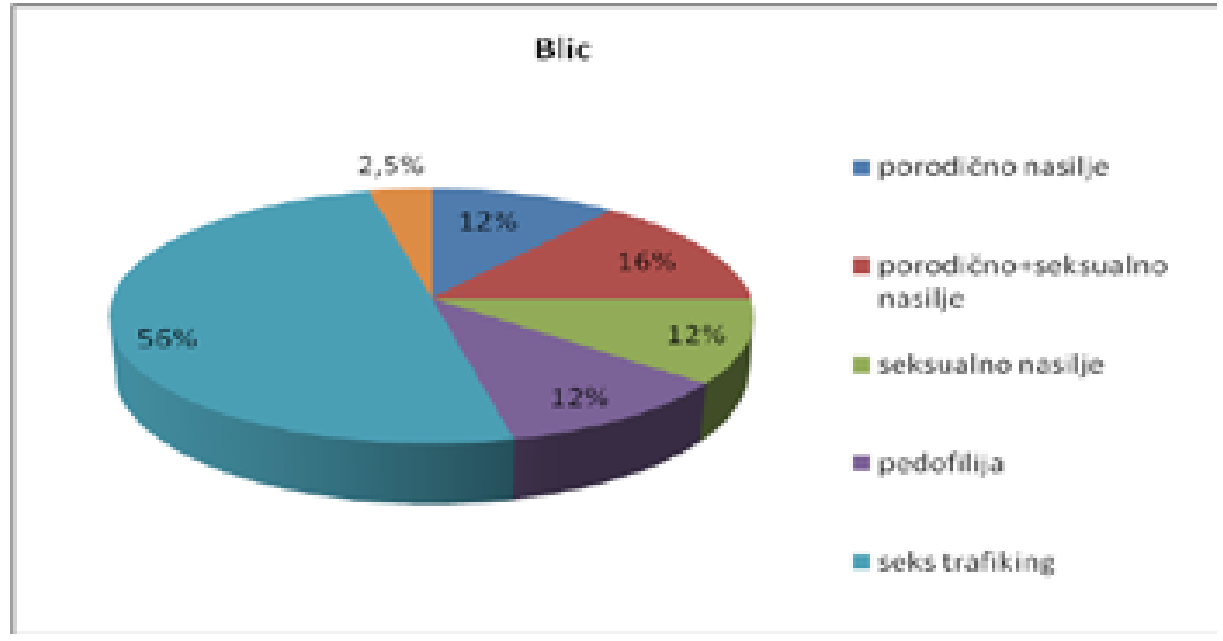

Grafikon 12. Teme izveštavanja - Blic

\subsubsection{Subjekat - ko govori?}

Na osnovu dobijenih rezultata, zapažamo da se u rumunskom dnevnom listu u ulozi subjekta najčešće pojavljuju deca - 29 puta $(71 \%)$, slede eksperti ${ }^{4}-4$ puta $(10 \%)$, predstavnici vlasti ${ }^{5}-3$ puta $(7 \%)$, roditelji - 2 puta $(5 \%)$, predstavnici institucija $^{6}-1$ put (2\%), predstavnici asocijacija ${ }^{7}-1$ put (2\%), 1 put (2\%) subjekt je neko drugi ${ }^{8}$.

U srpskom dnevnom listu na prvom mestu su deca - 15 puta (60\%), slede predstavnici vlasti ${ }^{9}-4$ puta $(16 \%)$, crkveni predstavnici ${ }^{10}-1$ put $(4 \%)$, roditelji -1 put (4\%), 1 put (4\%) subjekat je neko drugi ${ }^{11}$.

\footnotetext{
$4 \quad$ Psiholozi, socijalni radnik, lekar

5 Europol (Evropska policijska služba), Skotland Jard, rumunska policija

6 Direktorka Direkcije za zaštitu dece

7 Direktorka asocijacije „Dečji telefon”

8 Silovatelj dece iz Švajcarske

9 Policija, predsednica Skupštine, Slavica Đukić Dejanović, irski premijer, Euleks

10 Papa Benedikt XVI

11 Italijani koji protestvuju protiv seksualnog zlostavljanja dece od strane katoličkih sveštenika
} 


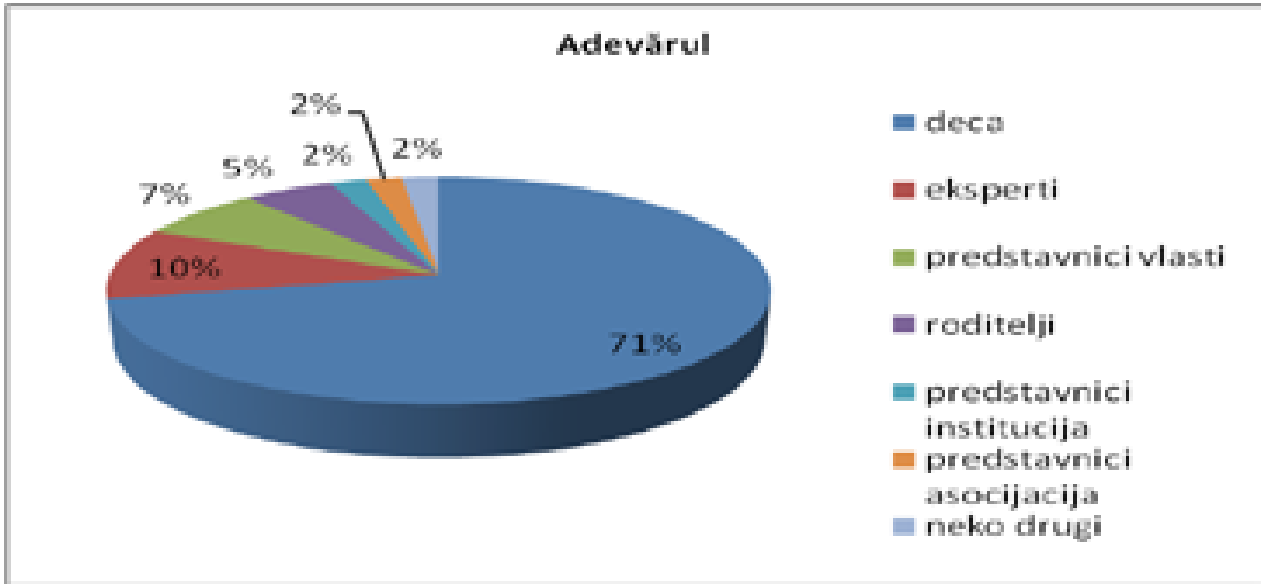

Grafikon 13. Subjekat - Adevărul

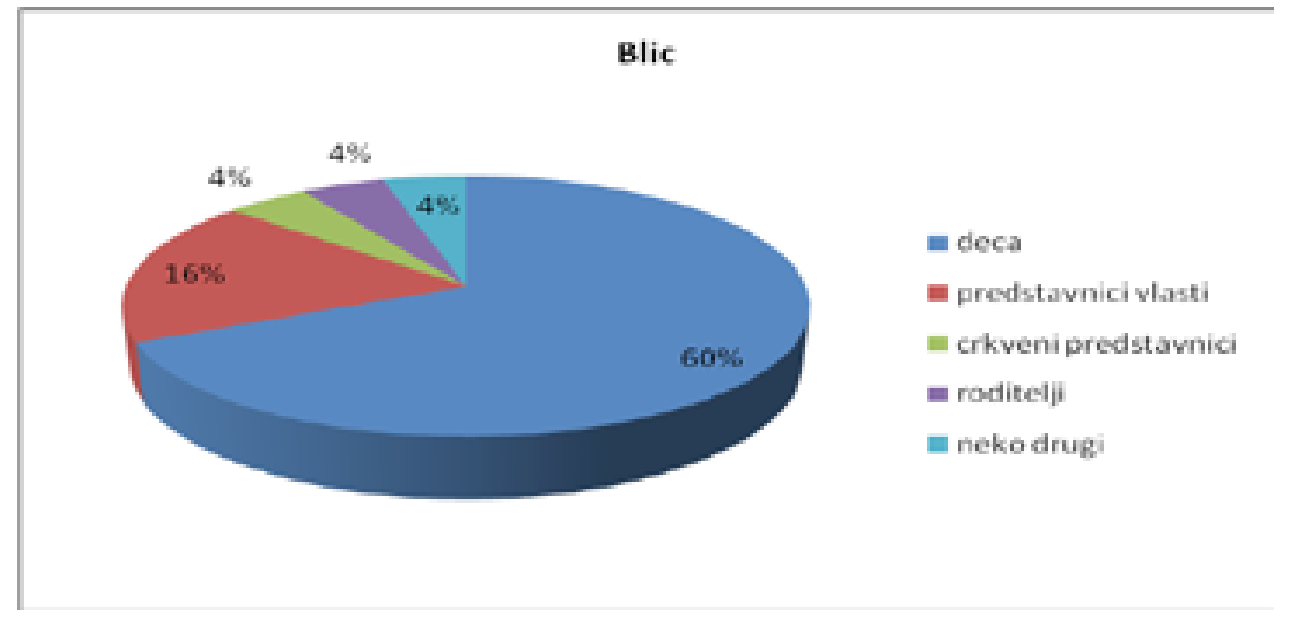

Grafikon 14. Subjekat - Blic

2.2.8. Objekat - o kome se govori?

U oba dnevna lista, najčešće se govori o roditeljima - 19 puta (44\%) u Adevărul, 8 puta (31\%) u Blicu. Uz roditelje, u ulozi objekta u Adevărul pojavljuju se i deca -12 puta (28\%), pedofili - 5 puta $(12 \%)$, rodbina ${ }^{12}-3$ puta $(7 \%)$, predstavnici

12 Baka, brat od tetke i sestra od tetke 
iz sveta obrazovanja ${ }^{13}-2$ puta (5\%), 1 put (2\%) objekat je neko drugi ${ }^{14}$, a 1 put ( $\left.2 \%\right)$ objekta nema (nije specifikovan).

U Blicu uz roditelje u ulozi objekta pojavljuju se i crkveni predstavnici ${ }^{15}$ - 6 puta (23\%), deca -4 puta (15\%), pedofili - 4 puta (15\%), trgovci decom - 1 put (4\%), eksperti ${ }^{16}$ - 1 put (4\%), predstavnici iz sveta obrazovanja ${ }^{17}-1$ put (4\%), građani - 1 put $(4 \%)$.

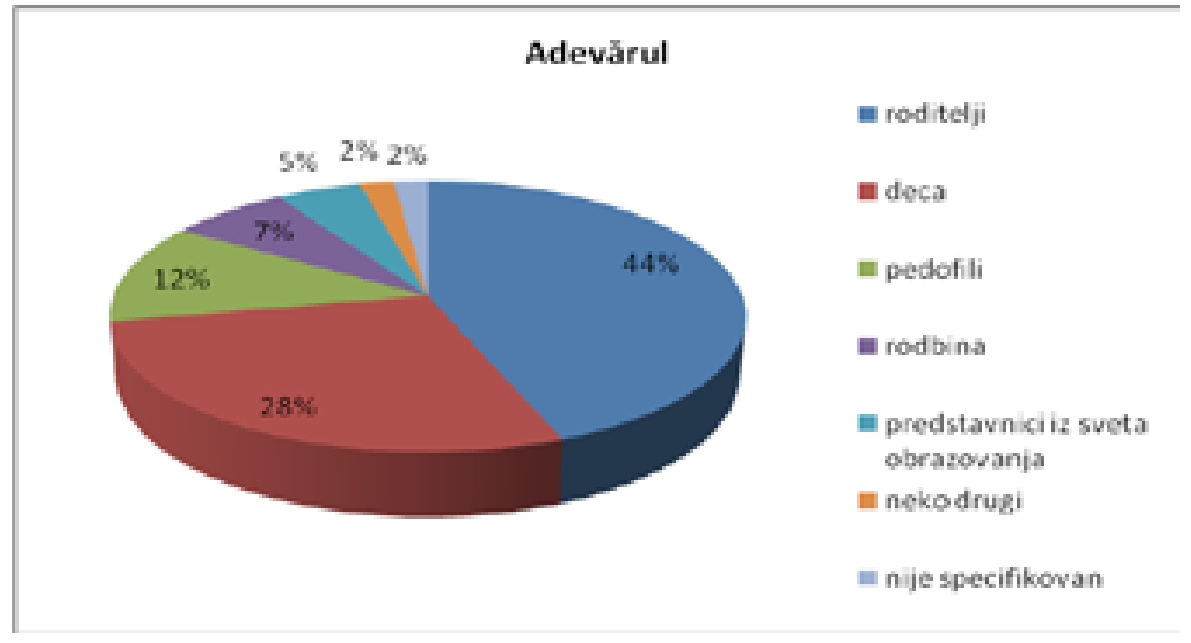

Grafikon 15. Objekat - Adevărul

\footnotetext{
$13 \quad$ Nastavnik i vaspitač

14 Tenkista silovatelj

15 Predstavnici Rimokatoličke crkve u Vatikanu, brazilski, nemački holandski, malteški sveštenici, kanadski biskup

16 Socijalni radnik

17 Profesor
} 


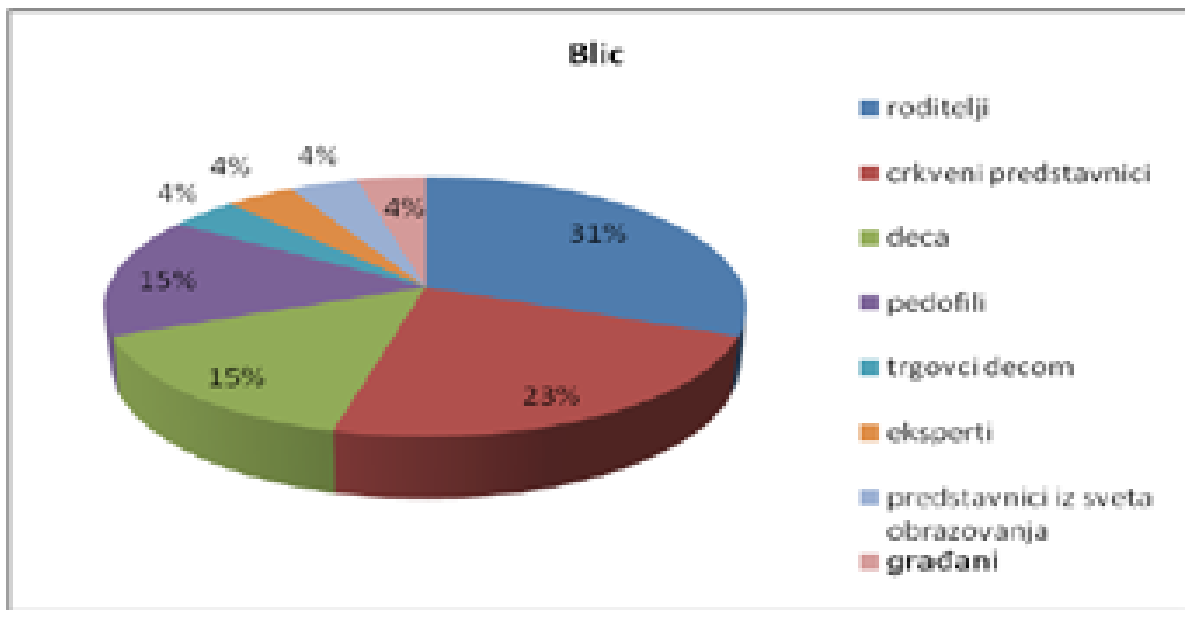

Grafikon 16. Objekat - Blic

2.2.10. Vrednosni kontekst u koji je postavljen objekat

U oba dnevna lista, vrednosni kontekst u koji je postavljen objekat je najčešće negativan - 32 puta (80\%) u Adevărul, 15 puta (60\%) u Blicu; uz negativan kontekst, beležimo i neutralan kontekst, 8 puta (20\%) u Adevărul, 10 puta (40\%) u Blicu.

\subsubsection{Tip naslova}

Tip naslova je u oba dnevna lista uvek realan. Dajemo primere:

- 60 de copii au fost abuzați de la începutul anului „60 dece zlostavljano od početka godine”; 31 de copii au fost abuzați sexual în 2010 „,31 dete seksualno zlostavljano u 2010." (Adevărul);

- Samo pet posto građana bi prijavilo zlostavljanje deteta; Seksualno zlostavljana deca godinama trpe nasilje (Blic).

\section{ZAKLJUČNE NAPOMENE}

$\mathrm{Na}$ osnovu analize istraživačkog korpusa, zaključujemo da se rumunski dnevni list Adevărul više bavio problemom zlostavljanja dece nego Blic (40 tekstova prema 25); iako je broj tekstova u Blicu na ovu temu manji, analiza je pokazala da postoje sličnosti, ali i razlike. 
Rukovodeći se kodeksom i rezultatima, zapažamo da, kada je u pitanju veličina teksta, skoro polovina tekstova u Adevărul spada u red velikih, dok su u Blicu najbrojniji tekstovi srednje dužine. Od žanrova, u oba list dominira članak, a isto važi i kada je u pitanju povod izveštavanja, gde je pažnja najčešće fokusirana na aktuelnom događaju. Kada je reč o vizuelnoj prezentaciji, u rumunskom listu fotografija prati svaki tekst, dok u srpskom dnevnom listu fotografija se pojavljuje u skoro jednoj trećini tekstova. Razlike postoje i kada je reč o autorstvu teksta; svi prilozi u rumunskom dnevnom listu su potpisani punim imenom i prezimenom novinara, dok je u srpskom dnevnom listu agencija najčešći izvor informisanja.

Kada je reč o lokaciji, rezultati su pokazali da postoje značajne razlike. Najčešće mesto zbivanja događaja u rumnskom listu je Rumunija, sledi Republika Moldavija, SAD, Velika Britanija i Švajcarka, kojih nema u Blicu. Sa druge strane, najčešće mesto zbivanja događaja u srpskom listu je Srbija, sledi region - Hrvatska, BiH i Makedonija, Kosovo, zatim Nemačka, Italija, Irska, Holandija, Malta, Kanada i Brazil, kojih uopšte nema u Adevărul. Od tema „tretira“ se nasilje nad decom, dok u kategoriji subjekat u oba lista prednjače deca, a pojavljuju se i eksperti, roditelji, predstavnici institucija i asocijacija (Adevărul), odnosno predstavnici vlasti, predstavnici crkve i roditelji (Blic). Sa druge strane, o roditeljima se najčešće govori u kategoriji objekat, i u Adevărul, i u Blicu. Na kraju treba još spomenuti da je u oba dnevna lista vrednosni kontekst u koji je postavljen objekat najčešće negativan, a tip naslova uvek realan.

\section{LITERATURA}

Banjanin-Đuričić, N. (1998). Udarac po duši-sociološka studija zlostavljanja dece u porodici. Beograd: Institut za kriminološka i sociološka istraživanja Jugoslovenski centar za prava deteta.

Gašić-Marušić, R. (1998). Zdravstveni aspekti nasilja nad decom, mogućnosti ranog otkrivanja i blagovremene zaštite. U Milosavljević, M. (ur.), Zaštita dece od zlostavljanja i zanemarivanja. Beograd: Službeni glasnik, str. 51.

Lakić, A. (1998). Emocionalno zanemarivanje i zlostavljanje dece. U Milosavljević, M. (ur.), Zaštita dece od zlostavljanja i zanemarivanja. Beograd: Službeni glasnik, str. 34-37. 
Mihić, Biljana (2002). Porodično nasilje nad decom. Temida. 5/3: 51-58.

Milosavljević, M. (1998). Nasilje nad decom. Beograd: Fakultet političkih nauka.

Mršević, Z., Milivojević. S., Ćopić, S. (2000). Deca-žrtve nasilja kriminološki, krivičnopravni i krivičnoprocesni aspekt. Temida. 1: 13-19.

Obretković, M. (1998). Pravna zaštita zlostavljane dece - da li je potrebna reforma našeg pravnog sistema? U Milosavljević, M. (ur.), Zaštita dece od zlostavljanja i zanemarivanja. Beograd: Službeni glasnik, str. 97-109.

Obretković, M. (1999). Multidisciplinarni model zaštite dece - žrtava nasilja. Temida. 3-4: 4.

Samardžić, Ljiljana, Nikolić, Ljiljana, Grbeša, Grozdanko, Simonović, Maja, Milenković, Tatjana (2010). Povezanost nepovoljnih iskustava u detinjstvu sa psihijatrijskim poremećajima i agresivnošću kod odraslih. Vojnosaniteteski pregled. 68/8: 653-658.

\section{INTERNET IZVORI \\ http://www.adevarul.ro/ \\ http://www.blic.rs/}

Laura Spariosu

\section{SERBIAN AND ROMANIAN DAILY NEWSPAPERS ABOUT CHILD ABUSE PROBLEM}

The aim of this paper is to research the way that Serbian and Romanian daily newspapers inform about child abuse problem. The main corpus will consist in articles published in the Serbian daily newspaper Blic and in Romanian daily newspaper Adevărul, from Janary $1^{\text {st }} 2011$ to January $31^{\text {st }} 2012$.

Child abuse is a phenomenon that integrates all activities, events, situations, conditions or behaviour that hurt child's integrity and harm its development. Child abuse involves: physical abuse, sexual abuse, emotional abuse and neglecting and child exploitation

Having all that in mind, it is the intention of the author to analyse texts about this issue according to the Codex that reffers to text length, journalistic genre, authorship, cause of reporting, visual presentation, location, topic, subject, object, value context, text title, in order to research how the selected media present the event and what is similar and what is different 
in the topic that is being researched.

Although in Romanian daily newspaper Adevărul more texts about child abuse problem were published than in Blic (40:25), according to the results it could be said that there were detected similarities, but also dissimilarities. Similar in both media are results related to journalistic genre, cause of reporting, visual presentation, topic, value context and text title; dissimilarities could be detected related to text lenght, authorship and location.

Keywords: daily newspapers, children, abuse, Adevărul, Blic 